\title{
Pengetahuan Pasangan Usia Subur Tentang Kanker Serviks
}

\author{
Sitti Aisa ${ }^{1}$ \\ ${ }^{I}$ Poltekes Kemenkes Kendari
}

\begin{tabular}{l}
\hline INFORMASI ARTIKEL: \\
\hline Riwayat Artikel: \\
Tanggal diterima: January 02, 2018 \\
Tanggal di revisi: March 12, 2018 \\
Tanggal di Publikasi: March 20, 2018 \\
\hline
\end{tabular}
Kata kunci:
Kata kunci : Pengetahuan, usia saat
menikah, informasi, kanker serviks,

Key word:

Knowledge, age at marriage, information, cervical cancer.

Contact:

sittiaisakeb@gmail.com

\begin{abstract}
A B S T R A K
Latar Belakang: Kanker serviks menduduki urutan ke 2 di Indonesia yang menyerang wanita usia 15-44 tahun dan menyebabkan ribuan kematian per tahunnya. Kanker ini sering dikaitkan dengan usia muda ketika pertama kali melakukan hubungan seks dan kurangnya informasi yang diperoleh yangmempengaruhi pengetahuan para ibu dalam pasangan usia subur tentang kanker serviks.

Tujuan penelitian: Untuk mengetahui hubungan umur dan informasi dengan pengetahuan ibu tentang kanker serviks.

Metode Penelitian: Penelitian analitik menggunakan rancangan crosssectional yang dilaksanakan di Puskesmas Poasia Kota Kendari Provinsi Sulawesi Tenggara pada bulan Desember 2017. Populasi adalah sebanyak 266 dan sampel diambil dengan tehnik accidental sampling, yaitu sebanyak 57. Data yang digunakan adalah data primer dan sekunder. Analisis data meliputi analisis univariat dan analisis bivariat dengan menggunakan uji Chi-Square.

Hasil Penelitian: Hasil analisis statistik untuk variabel usia saat menikah dengan pengetahuan tentang kanker serviks dengan uji chi-square menunjukkan X2 hitung $(6,92)$ lebih besar dari X2 tabel $(3,841)$. Untuk variabel informasi, X2 hitung $(10,07)$ juga lebih besar dari X2 tabel pada 3,841. Dengan demikian, terdapat hubungan antara usia saat menikah dan informasi yang diperoleh PUS dengan pengetahuan tentang kanker serviks. Kesimpulan dan Saran: Usia saat menikah dan informasi yang diperoleh berhubungan dengan pengetahuan tentang kanker serviks. Para ibu dari pasangan usia subur disarankan untuk meningkatkan pengetahuan tentang kanker serviks dengan mengikuti penyuluhan yang disampaikan oleh tenaga kesehatan untuk dapat melindungi diri dari ancaman kanker serviks.
\end{abstract}

\section{A B S T R A C T}

Background: Cervical cancer ranks 2nd in Indonesia that attacks women aged 15-44 years and causes thousands of deaths per year. It is often associated with young age when first having sex and the lack of information obtained affects the knowledge of mothers in fertile couples about cervical cancer.

Objective: To determine the relationship of age and information to maternal knowledge about cervical cancer.

Method: The analytic study used a cross-sectional design which was conducted at Poasia Health Center of Kendari City, Southeast Sulawesi Province in December 2017. Population was 266 and samples were taken with accidental sampling technique, ie., 57 . The data used were primary and secondary data. Data analysis included univariate and bivariate analysis using Chi-Square test.

Results: Statistical analysis for age when married with knowledge of cervical cancer showed X2 count (6.92) was greater than X2 table $(3,841)$. For information variable, X2 count (10.07) was also greater than X2 table at 3.841. Thus, there was a relationship between the age at marriage and information obtained by women and knowledge of cervical cancer.

Conclusion and Suggestion: Age at marriage and information obtained related to knowledge about cervical cancer. The women are advised to increase knowledge about cervical cancer by following the counseling delivered by health workers to be able to protect themselves from the threat of cervical cancer. 


\section{PENDAHULUAN}

Di seluruh dunia, sekitar 500.000 perempuan didiagnosis dengan kanker serviks pada tahun 2008, dengan 274.000 perkiraan kematian (Ferlay et al., 2010). Menurut World Health Organization (2013), kanker serviks disebabkan oleh infeksi virus HPV (Human Papilloma Virus) yang tidak sembuh dalam waktu yang lama. Jika kekebalan tubuh berkurang, infeksi ini bisa mengganas dan menyebabkan terjadinya kanker serviks. Terdapat sekitar 266.000 kematian akibat kanker serviks di seluruh dunia pada tahun 2012 dan 94 kematian akibat kanker serviks di Asia Tenggara (WHO, 2013). Menurut data Yayasan Kanker Indonesia (YKI), terdapat lebih dari 15.000 kasus kanker serviks baru di Indonesia yang telah merenggut 8000 kematian setiap tahunnya.

Human Papilloma Virus yang dianggap sebagai kunci awal dari kanker mulut rahim terus diteliti hingga akhirnya suatu pola pemikiran untuk mencegah kanker mulut rahim dikembangkan dengan vaksin terhadap infeksi Human Papilloma Virus (Rasjidi, 2011). Pemerintah Indonesia memang sudah memperluas pelaksanaan deteksi dini kanker serviks, misalnya, hingga tahun 2013 pelaksanaan ini sudah menjangkau 140 kabupaten di 31 provinsi dan dilaksanakan oleh 500 dari 9.500 puskesmas di Indonesia (Depkes RI, 2013).

Melakukan hubungan seksual di usia muda merupakan salah satu risiko terjadinya kanker serviks ini. Semakin muda usia pertama kali berhubungan sex, semakin besar risiko daerah reproduksi terkontaminasi virus (Plummer, dkk, 2012). Pengetahuan yang baik dapat meningkatkan upaya promotif-preventif, antara lain dengan melaksanakan sosialisasi, advokasi, dan edukasi di berbagai elemen masyarakat. Edukasi akan lebih efektif jika dilakukan lebih awal, antara lain pada ibu-ibu pasangan usia subur melalui tenaga kesehatan (Depkes RI, 2013). Penelitian ini bertujuan untuk menentukan hubungan umur dan informasi dengan pengetahuan ibu tentang kanker serviks.

\section{METODE PENELITIAN}

Penelitian analitik ini menggunakan rancangan penelitian cross-sectional. Pengukuran variabel dilakukan pada suatu saat, yang berarti bahwa subjek penelitian hanya diobservasi pada saat yang sama dan pengukuran variabel dilakukan pada saat pemeriksaan atau pengkajian (Notoatmodjo, 2010). Penelitian dilaksanakan pada bulan Desember 2017 di Puskesmas Poasia Kota Kendari Provinsi Sulawesi Tenggara.

Populasi dalam penelitian ini adalah semua ibu dari PUS yang datang ke Poliklinik KIA/KB Puskesmas Poasia Kota Kendari Provinsi Sulawesi Tenggara pada bulan Januari s/d November 2017, yaitu sebanyak 266 orang. Dari populasi tersebut, sampel penelitian ini adalah sebahagian PUS yang datang ke poli klinik KIA KB Puskesmas Poasia Kota Kendari Provinsi Sulawesi Tenggara pada bulan Januari s/d November 2017. Besar sampel yang digunakan dalam penelitian ini adalah 57 ibu yang dipilih dengan metode accidental sampling. Pengambilan sampel ditentukan berdasarkan kriteria inklusi dan kriteria eksklusi agar sampel tidak menyimpang dari populasi (Notoatmojo, 2010). Kriteria inklusinya termasuk ibu yang menggunakan kontrasepsi, ibu yang melakukan pemeriksaan IVA, dan ibu yang bersedia menjadi responden penelitian. Untuk kriteria eksklusi, ibu yang sedang hamil dan ibu yang tidak bersedia menjadi responden dimasukkan dalam kriteria ini.

Data yang dikumpulkan terdiri atas data primer dan data sekunder. Data primer diperoleh melalui kuesioner yang diberikan kepada responden untuk menilai pengetahuan, mendata usia saat menikah dan mendapatkan informasi yang diperoleh PUS tentang kanker serviks sedangkan data sekunder diambil dari buku register yang ada di Poli KIA/KB Puskesmas Poasia Kota Kendari Provinsi Sulawesi Tenggara tahun 2017. Setelah data terkumpul, langkah yang dilakukan berikutnya adalah pengolahan data (Arikunto, 2010) melalui editing, coding, entry, dan tabulating. Untuk 
analisis data, analisis univariat dan bivariat digunakan dengan analisis bivariat yang dilakukan dengan uji statisti chi-square (X2).

\section{HASIL PENELITIAN}

\section{Tabel 1. Distribusi Pengetahuan PUS}

\begin{tabular}{|c|c|c|}
\hline Pengetahuan & Jumlah (n) & Persentase (\%) \\
\hline Baik & 39 & 68,4 \\
\hline Kurang & 18 & 31,6 \\
\hline Total & $\mathbf{5 7}$ & 100 \\
\hline
\end{tabular}

Tabel 1 menunjukkan bahwa $39 \quad(68,4 \%)$ responden memiliki pengetahuan yang baik dan hanya $18 \quad(31,6 \%)$ responden memiliki pengetahuan kurang.

Tabel 2. Distribusi Sampel Menurut Umur PUS saat menikah

\begin{tabular}{|c|c|c|}
\hline Usia Saat Manikah & \multicolumn{2}{|c|}{ Jumlah } \\
\cline { 2 - 3 } & Total & Persentase (\%) \\
\hline Usia ideal & 47 & 82,4 \\
\hline Usia Muda & 10 & 17,6 \\
\hline Total & $\mathbf{5 7}$ & $\mathbf{1 0 0}$ \\
\hline
\end{tabular}

Berdasarkan Tabel 2, dari 57 responden yang menikah, $47(82,4 \%)$ responden menikah pada usia ideal sedangkan $10(17,6 \%)$ responden menikah pada usia yang masih muda.

Tabel 3. Distribusi Sampel Menurut Informasi yang Diperoleh PUS

\begin{tabular}{|c|c|c|}
\hline \multirow{2}{*}{$\begin{array}{c}\text { Informasi yang } \\
\text { diperoleh }\end{array}$} & \multicolumn{2}{|c|}{ Jumlah } \\
\cline { 2 - 3 } & Total & Persentase (\%) \\
\hline Nakes & 36 & 63,2 \\
\hline Non-Nakes & 21 & 36,8 \\
\hline Total & $\mathbf{5 7}$ & $\mathbf{1 0 0}$ \\
\hline
\end{tabular}

Tabel 3 menunjukan bahwa, dari 57 responden, informasi dari yang diperoleh dari nakes dinyatakan oleh $36 \quad(63,2 \%)$ responden sedangkan $21(36,8 \%)$ responden mendapatkan informasi dari non-nakes.

Tabel 4. Hubungan Usia saat Pernikahan dengan Pengetahuan tentang Kanker Serviks

\begin{tabular}{|c|c|c|c|c|c|c|}
\hline \multirow{2}{*}{$\begin{array}{c}\text { Usia PUS } \\
\text { Saat Menikah }\end{array}$} & \multicolumn{3}{|c|}{$\begin{array}{c}\text { Pengetahuan tentang Kanker } \\
\text { Serviks }\end{array}$} & \multicolumn{2}{|c|}{ Total } \\
\cline { 2 - 5 } & \multicolumn{2}{|c|}{ Baik } & \multicolumn{2}{c|}{ Kurang } & \multicolumn{2}{c|}{} \\
\cline { 2 - 5 } & $\mathbf{n}$ & $\%$ & $\mathbf{n}$ & $\%$ & $\mathbf{N}$ & $\%$ \\
\hline Usia Ideal & 36 & 63,1 & 11 & 19,3 & 47 & 82,4 \\
\hline Usia Muda & 3 & 5,3 & 7 & 12,3 & 10 & 17,6 \\
\hline Total & $\mathbf{3 9}$ & $\mathbf{6 8 , 4}$ & $\mathbf{1 8}$ & $\mathbf{3 1 , 6}$ & $\mathbf{5 7}$ & $\mathbf{1 0 0}$ \\
\hline
\end{tabular}

Berdasarkan hubungan umur dengan pengetahuan responden, dari 57 responden, 47 $(82,4 \%)$ responden menikah dengan usia ideal dan $36(63,1 \%)$ di antaranya memiliki pengetahuan baik dan $11(19,3 \%)$ memiliki pengtahuan kurang. Untuk $10 \quad(17,6 \%)$ responden dengan usia muda sebanyak, $7(12,3)$ di antaranya memiliki pengetahuan kurang dan 3 $(5,3 \%)$ memiliki pengetahuan baik.

Hasil analisis statistik menggunakan uji chisquare test menunjukkan bahwa $\mathrm{X}^{2}$ hitung adalah 6,92 yang lebih besar dari $\mathrm{X}^{2}$ tabel, yaitu 3,841 pada $\alpha 0,05$ dan $\mathrm{df}=1$. Hal ini dianggap bermakna sehingga terdapat hubungan antara usia saat menikah dengan pengetahuan tentang kanker serviks.

Tabel 5. Hubungan Informasi yang Diperoleh PUS dengan Pengetahuan PUS tentang Kanker

\begin{tabular}{|c|c|c|c|c|c|c|}
\hline \multirow{3}{*}{$\begin{array}{c}\text { Informasi } \\
\text { yang } \\
\text { diperoleh } \\
\text { PUS }\end{array}$} & \multicolumn{4}{|c|}{$\begin{array}{c}\text { Pengetahuan Tentang Kanker } \\
\text { Serviks }\end{array}$} & \multirow{2}{*}{\multicolumn{2}{|c|}{ Total }} \\
\hline & \multicolumn{2}{|c|}{ Baik } & \multicolumn{2}{|c|}{ Kurang } & & \\
\hline & $\mathbf{n}$ & $\%$ & $n$ & $\%$ & $\mathbf{N}$ & $\%$ \\
\hline Nakes & 30 & 52,6 & 6 & 10,5 & 36 & 63,2 \\
\hline Non-Nakes & 9 & 158 & 12 & 21.1 & 21 & 36.8 \\
\hline Total & 39 & 68,4 & 18 & 31,7 & 57 & 100 \\
\hline
\end{tabular}

Dari 57 responden, jumlah responden yang memperoleh informasi dari nakes adalah 36 $(63,2 \%)$ dan $30(52,6 \%)$ di antaranya memiliki pengetahuan baik sedangkan $6(10,5 \%)$ memiliki pengetahuan kurang. Untuk $21 \quad(36,8 \%)$ responden yang memperoleh informasi dari nonnakes sebanyak, $12(21,1)$ di antaranya memiliki pengetahuan kurang dan $9(15,8 \%)$ memiliki pengetahuan baik.

Hasil analisis statistik dengan menggunakan uji chi-square test menunjukkan bahwa $\mathrm{X}^{2}$ hitung adalah 10,07 yang lebih besar dari $\mathrm{X}^{2}$ tabel, yaitu 3,841 pada $\alpha 0,05$ dan $\mathrm{df}=1$. Hasil penghitungan ini adalah bermakna sehingga terdapat hubungan antara informasi yang diperoleh dengan pengetahuan tentang kanker serviks. 


\section{PEMBAHASAN}

\section{Hubungan usia pernikahan dengan pengetahuan tentang kanker serviks}

Dalam penelitian ini terdapat hubungan antara usia saat menikah dengan pengetahuan tentang kanker. Notoatmodjo (2010) menjelaskan bahwa pengetahuan (knowledge) diartikan sebagai hasil penginderaan manusia atau hasil tahu seseorang terhadap objek melalui indra yang dimilikinya (mata, hidung, dan sebagainya), dengan sendirinya pada waktu pengindraan sehingga pengetahuan dihasilkan. Hal tersebut sangat dipengaruhi oleh intensitas perhatian dan persepsi terhadap objek.

Hasil penelitian ini menunjukkan bahwa masih banyak responden yang tidak mengetahui bahwa kanker serviks adalah jenis kanker yang dapat dicegah sehingga dapat berimbas pada peningkatan jumlah penderita kanker serviks. Hal inilah yang menyebabkan masih tingginya angka kematian yang disebabkan oleh kanker jenis ini karena penderitanya datang ke fasilitas kesehatan untuk memeriksakan diri saat kanker sudah mencapai stadium lanjut (Rasjidi, 2007).

Usia saat pernikahan akan mempengaruhi pengetahuan dalam kesehatan reproduksi. Orang usia muda masih belajar menerima informasi tetapi belum mampu menerapkan informasi tersebut secara maksimal dan seringkali mencoba-coba tanpa memperhitungkan konsekuensinya. Menikah pada usia ideal mulai memahami dirinya dan lebih mudah menerima informasi sehingga hal ini mempengaruhi pengetahuan mereka.

Penelitian ini sejalan dengan penemuan dari penelitian Mukama dkk (2017) bahwa melakukan hubungan seks pada usia muda akan menyebabkan tingkat kanker serviks yang meninggi. Hubungan seks yang dilakukan pada usia muda tersebut disebabkan oleh kurangnya pengetahuan tentang kanker seviks. Sebaliknya, semakin bertambahnya umur, pengetahuan yang dimiliki seseorang juga akan semakin banyak dan beragam, termasuk pengetahuan tentang kanker serviks. Berhubungan dengan penelitian ini, seiring dengan usia ideal saat pernikahan, pengetahuan tentang kanker serviks yang dimiliki ibu diharapkan dapat mengembangkan kemampuan mereka dalam mengambil keputusan untuk melakukan upaya perlindungan diri atau pencegahan dari kanker mematikan seperti kanker serviks.

\section{Hubungan Informasi yang diperoleh dengan Pengetahuan tentang kanker serviks.}

Hasil penelitian ini menyatakan bahwa pengetahuan responden tentang kanker serviks ternyata dipengaruhi pula oleh dari mana informasi yang diperoleh. Peneliti berasumsi bahwa informasi yang diserap baik dari nakes maupun non-nakes memberikan kontribusi pada tingkat pengetahuan. Hal ini dibenarkan oleh Mubarak (2011) yang mengatakan bahwa informasi menjadi salah satu faktor yang mempengaruhi pengetahuan.

Informasi menjadi salah satu organ pembentuk pengetahuan dan memegang peranan besar dalam membangun pengetahuan. Semakin banyak seseorang memperoleh informasi, semakin baik pula pengetahuannya, dan begitu pula sebaliknya. Berdasarkan hasil penelitian, sebagian responden memperoleh informasi tentang kanker serviks dari non-nakes yang memiliki pengetahuan kurang. Oleh karena itu, informasi seputar kanker serviks tidak banyak diketahui.

Penelitian ini sejalan dengan penelitian Phillips dkk (2003) yang menyatakan bahwa informasi tentang kanker serviks akan memberikan pengetahuan kepada para perempuan. Oleh karena itu, informasi yang diterima secara benar dari tenaga kesehatan yang berkualitas akan memberikan pengetahuan yang benar pula kepada para perempuan tentang kanker serviks ini sehingga para perempuan tersebut dapat mengambil langkah preventif dalam mencegah terjadinya kanker ini. 


\section{KESIMPULAN}

Usia pernikahan berhubungan dengan pengetahuan tentang kanker serviks dan terdapat hubungan antara informasi yang diperoleh ibu, yaitu dari nakes dan non-nakes dengan pengetahuan tentang kanker serviks.

\section{SARAN}

Pasangan usia subur perlu untuk menambah pengetahuan tentang kanker serviks dengan mengikuti penyuluhan kesehatan yang disampaikan oleh tenaga kesehatan untuk dapat melindungi diri dari ancaman kanker serviks. Petugas kesehatan juga diharapkan untuk meningkatkan penyuluhan kepada pasangan usia subur tentang kanker serviks dan menerapkan pelayanan kesehatan yang terjangkau oleh masyarakat.

\section{DAFTAR PUSTAKA}

Arikunto, 2010. Prosedur Penelitian Suatu Pendekatan Praktik. Jakarta : Rineka Cipta.

Depkes RI, 2013. Pemerintah Targetkan 80\% Perempuan Dapat Deteksi Dini Kanker Payudara dan Kanker Serviks. http://www.depkes.go.id/index.php?vw=2 \&id=SNR.13100003. diakses tanggal 15 Desember 2017.

Ferlay J., Shin H.-R., Bray F., Forman D., Mathers C., Parkin D. M. Estimates of worldwide burden of cancer in 2008: GLOBOCAN 2008. 2010. International Journal of Cancer. ;127:28932917.doi:10.1002/ijc. 25516.

Mubarak, 2011. Promosi Kesehatan Sebuah Pengantar Proses Belajar Mangajar dalam Pendidikan. Yogyakarta: Graha Ilmu.
Mukama, Trasias et al. 2017. "Women's Knowledge and Attitudes towards Cervical Cancer Prevention: A Cross Sectional Study in Eastern Uganda." BMC Women's Health 17: 9. PMC.

Notoatmodjo. 2010. Metode penelitian kesehatan. Jakarta : Rineka Cipta.

Notoatmodjo. 2010. Pendidikan dan Perilaku Kesehatan. Jakarta : Rineka Cipta.

Phillips et all. 2003. Health Education Research, Volume 18, Issue 3, 1 June 2003, Pages $318-$

328,https://doi.org/10.1093/her/cyf022

Plummer M, Julian P, and Silvia on behalf of the International Collaboration of Epidemiological Studies of Cervical Cancer. 2012. "Time since First Sexual Intercourse and the Risk of Cervical Cancer." International journal of cancer. Journal international du cancer 130.11: 2638-2644. PMC.

Rasjidi. 2007. Vaksin Human Papilloma Virus dan Eradiksi Kanker Mulut Rahim. Malang : Sugeng Seto.

Rasjidi. 2011. 100 Questions \& Answers : Kanker pada Wanita.Jakarta : Elex Media Komputindo.

World Health Organization. WHO. 2013. Comprehensive Cervical Cancer Prevention And Control : A Healthier Future For Girls and Women.(online)(http://apps.who.int/iris/bi tstream/10665/78128/3/9789241505147_e ng.pdf) diakses tanggal 15 Desember 2017. 